\title{
Notes
}

\section{A License To Abuse: The Impact of Conditional Status on Female Immigrants}

\author{
Michelle J. Anderson
}

Maria was born in the Dominican Republic. She married a United States citizen, immigrated to this country, and obtained "conditional" resident immigration status, which enabled her to remain legally in the United States provided that she stay wedded to her spouse. Soon afterward, her husband began to brutalize her physically. "One time I had eight stitches in my head and a gash on the other side of my head, and he broke my ribs. . . . He would bash my head against the wall while we had sex. He kept threatening to kill me if I told the doctor what happened." Afraid of the risk of deportation, Maria endured her husband's treatment for months. After she finally fled, her spouse demanded that she return to his apartment for her immigration documents. At first, she told him, "No, you're going to hit me." But then she realized that she had to go because she needed the papers. She described the consequences: "He beat me on the head. He sat on my stomach. He put a knife to my throat and raped me. Then he threw me naked on the street."2

1. Vivienne Walt, Immigrant Abuse: Nowhere to Hide, NEWSDAY, Dec. 2, 1990, at 8.

2. Id. The severe abuse Maria endured after fleeing her battering relationship is consistent with patterns of increased abuse when women attempt to terminate or just after women terminate battering relationships. See Martha R. Mahoney, Legal Images of Battered Women: Redefining the Issue of Separation, $90 \mathrm{MiCH}$. L. REV. 1, 61-75 (1991) (defining "separation assault" and describing the incidence of separation attacks); Margo Wilson \& Martin Daly, Till Death Us Do Part, in FeMICIDE: The POLITICS OF WoMAN KILling 83, 89 (Jill Radford \& Diana E.H. Russell eds., 1992) [hereinafter FEMICIDE]. 
Sue, ${ }^{3}$ a Chinese national, immigrated and obtained conditional residency after marrying a U.S. citizen. Like Maria, Sue had to remain married to maintain her legal immigration status. Unfortunately, the similarities did not end there. Sue's husband repeatedly beat her. "You do exactly what I say, or I'll call Immigration," her husband warned, kicking her in the neck and face. "You need me." Sue feared she would not live. "Her story is typical of the battered immigrant women we see," explains Beckie Masaki, Executive Director of San Francisco's Asian Women's Shelter. "The batterer uses his citizenship to control and humiliate his wife." ${ }^{\prime 4}$ Pat Eng, founder of the New York Asian Women's Center, concurs, "Batterers invariably use[] the threat of deportation as a weapon in the abuse of their alien wives."

Female conditional residents are at risk for abuse due not only to their status as women in a culture in which violence against women is relatively common, ${ }^{6}$ but also to their position as immigrants who marry citizens or legal permanent residents (LPR's). ${ }^{7}$ Studies vary widely in estimating the

3. Not her real name.

4. Deanna Hodgin, 'Mail-Order' Brides Marry Pain to Get Green Cards, WASH. TMMS, Apr. 16, 1991, at E1; see also Jorge Banales, Abuse Among Immigrants: As Their Numbers Increase So Does the Need for Services, WASH. POST, Oct. 16, 1990, at E5 ("The 1986 Immigration Reform Act and the Immigration Marriage Fraud Amendment have combined to give the spouse applying for permanent residence a powerful tool to control his partner."); Nancy A. Fellom, Fear and Loathing in America: Alien Spouses Held Hostage Under Threat of Deportation Are Rescued from Abusive Partners by Amendments to Immigration Act, RECORDER, Aug. 15, 1991, at 4 (pointing out that immigrant remained "almost completely dependent on the continued goodwill of the resident benefactor, under threat of deportation if [she] went against [his] will"). For other stories of battered conditional residents, see CHRIS HOGELAND \& KAREN ROSEN, DREAMS LOST, DREAMS FOUND: UNDOCUMENTED WOMEN IN THE LAND OF OPPORTUNITY 12-13 (1991); Rachel Morello Frosch \& Trinidad Madrigal, Introduction to DOMESTIC VIOLENCE IN IMMIGRANT AND REFUGEE COMMUNITIES: ASSERTING THE RIGHTS OF BATTERED WOMEN I-1, 2 (Deeana Jang et al. eds., 1991) [hereinafter DOMESTIC VIOLENCE].

5. Hodgin, supra note 4; see also Debbie Lee, Identifying Immigrant Battered Women, in DOMESTIC VIOLENCE, supra note 4 , at II-3.

6. See, e.g., Wilson \& Daly, supra note 2, at 96 ("Women in the United States today face a statistical risk of being slain by their husbands that is about five to ten times greater than that faced by their European counterparts, and in the most violent American cities, the risk is five times higher again."); Janet Bass, More Women Raped in 1990 than Any Year in U.S. History, UPI, March 22, 1991, available in LEXIS, Nexis Library, UPI File (despite cross-national reporting differences which may account for some of the disparity, surveys indicate that "[t]he 1990 U.S. rape rate was 20 times higher than in Portugal, 26 times higher than in Japan, 15 times higher than in England, eight times higher than in France, 23 times higher than in Italy and 46 times higher than in Greece"). Furthermore, the incidence of rape in this country may be rising. See Survey Shows Rape Leads Violent-Crime Increase, N.Y. TiMES, Apr. 20, 1992, at B12 (citing an estimate from the Bureau of Justice Statistics that puts number of rapes and attempted rapes in 1991 up 59\% from the previous year); Eloise Salholz, Women Under Assault, NEwSWEEK, July 16, 1990, at 23 (citing FBI statistics that show rape rate "increasing at four times the rate of other crimes"). The increased numbers may not be solely attributable to increased reporting rates. See, e.g., Jane Caputi \& Diana E.H. Russell, Femicide: Sexist Terrorism against Women, in FEMICIDE, supra note 2, at 16-17 (documenting dramatic increase in the incidence of unreported violence against women over the past 50 years); Michael Isikoff, Record Number of Rapes Reported in U.S. in '90, WASH. POST, Mar. 22, 1991, at A3 (citing Senate Judiciary Committee national study revealing dramatic increase in unreported rapes which concludes, "This data ... silences the skeptics who believe that the rising rape rates are nothing more than a function of more women reporting their rapes to the police.").

7. Though the arguments presented in this Note also apply to abused conditional residents who are male, I address the plight of female conditional residents for two reasons. First, in the past 30 years, women have consistently comprised a majority of all documented and undocumented immigrants to the United 
percentage (between 12-50\%) of all married women who experience some form of domestic battery in their lives. ${ }^{8}$ Whatever the rate in the general population, the percentage for immigrant women is probably higher. ${ }^{9}$ Linguistic and cultural differences between spouses may hamper communication, tolerance, and understanding. ${ }^{10}$ The immigrant wife may be economically ${ }^{11}$ and psychologically ${ }^{12}$ dependent upon her spouse, limiting her alternatives to the relationship and placing her at increased risk for domestic violence. ${ }^{13}$ Stresses associated with migration itself, discrimination

States. Marion F. Housten et al., Female Predominance in Immigration to the United States Since 1930: A First Look, 18 INT'L MIGRATION REV. 908, 913, 922 (1984). Second, women comprise the vast majority of the victims of domestic assault. LEWIS OKUN, WOMAN ABUSE: FACTS REPLACING MYTHS 39-42 (1986). Though women can physically assault men, Dr. Angela Browne of the University of Massachusetts Medical School points out that "[w]omen abused by male partners tend to sustain multiple injuries to multiple sites of the body, an injury pattern not seen in men assaulted by female partners." Tamar Lewin, Battered Men Sounding Equal-Rights Battle Cry, N.Y. TIMES, Apr. 20, 1992, at A12.

8. For a survey of the available studies documenting the incidence of domestic battery, see ROBERT T. SigleR, DOMESTIC VIOLENCE IN CONTEXT: AN ASSESSMENT OF COMMUNTTY ATTITUDES 12-13 (i989); see also OKUN, supra note 7, at 37-39; MILDREd DALEY PAGELOW, FAMILY VIOLENCE 42-46 (1984).

9. Exact numbers are difficult to gauge, but various reports suggest that the population of abused immigrant women is very large. Preliminary data from a random sample survey of 157 undocumented Latinas in the D.C. metropolitan area indicates, for instance, that $60 \%$ of undocumented women report that they are battered by their spouses. Of those women who are married to citizens or LPRs (but have not obtained conditional resident status), the rate is reported at $77 \%$. Telephone Interview with Leslye Orloff, Director of Program Development, Ayuda of Washington D.C. (Mar. 23, 1993). See also James Leung, Law Benefiting Immigrant Wives Means More Work for Shelter, S.F. CHRON., Feb. 20, 1991, at B12 (indicating that domestic violence problem is on the rise); Wendy Lin, Is INS Hindering Abused Wives? Rules Said to Undermine Law Meant to Help Them, NEWSDAY, July 8, 1991, at 21 (noting that in 1990 half of battered clients at New York Asian Women's Center in Manhattan were conditional residents and $90 \%$ of victims of domestic violence at the Victims' Services Agency office in Jackson Heights, Queens were immigrants); see also Telephone Interview with Debbie Lee, Senior Program Coordinator, Family Violence Prevention Fund of San Francisco, Cal. (Mar. 10, 1992) [hereinafter Lee Interview] (characterizing battered conditional residents as "hidden population").

10. See infra notes $31-33$ and accompanying text.

11. Often conditional residents lack independent financial resources. See Fellom, supra note 4 ("The declining budgets and shrinking resources of social services agencies, coupled with language barriers, are very real obstacles for immigrant women and children, many of whom live at or below the poverty level. There are often no close friends or family to assist."); see also infra note 106 and accompanying text.

12. Often conditional residents do not have a sense of the social and legal realities of a highly bureaucratic state. Estelle Chun, Deputy Director of the Asian Pacific American Legal Center in Los Angeles, explains,

Battered conditional spouses often think that if they flee an abusive husband, the husband can just snap his fingers and the INS will come knocking at the door to put them on a plane the next day for their old country. The citizen is much more sophisticated about the laws and the culture; the immigrant often cannot speak English. The exploitation is so apparent.

Telephone Interview with Estelle Chun, Deputy Director of the Asian Pacific American Legal Center of Los Angeles, Cal. (Mar. 10, 1992) [hereinafter Chun Interview]; see also HoGELAND \& RosEN, supra note 4, at 16 (discussing dependence inhibiting battered immigrant from seeking help) and 19 (discussing widespread misinformation in immigrant communities); Frosch \& Madrigal, Introduction to DoMISTIC VIOLENCE, supra note 4, at I-1; Debbie Lee, Identifying Immigrant Battered Women, in DOMESTIC VIOLENCE, supra note 4, at II-2.

13.

[W]omen whose dependency on marriage is high tend to experience more physical abuse from their husbands than women whose dependency is low .... [W]ives who are highly dependent on marriage are less able to discourage, avoid, or put an end to abuse than are women in marriages where the balance of resources between husbands and wives is more nearly equal. Dependent wives have fewer alternatives to marriage and fewer resources within the marriage 
against racial minorities in this country, poverty, unemployment, and crowded living conditions heighten the chance that a husband will become abusive. ${ }^{14}$ Forty-eight percent of Latinas in a Coalition for Immigrant Rights and Services study reported that domestic violence against them had increased since they immigrated to the United States. ${ }^{15}$ Therefore, conditional resident status affects the lives of women who already face an enhanced risk of domestic violence from their partners.

A statute designed to combat an exaggerated claim of marital fraud, a well-intentioned amendment to limit the statute's draconian effects on battered women, and a meager interpretation of that amendment by the Immigration and Naturalization Service (INS) constitute the conditional residency laws that affect the lives of immigrant women. Like prior laws, but with new presumptions and procedures, the Immigration Marriage Fraud Amendments (IMFA) of 1986 authorize the INS to scrutinize immigrants' nuptial ties to citizens or LPR's in an effort to discover and deport any alien who obtained immigration status fraudulently, through a bogus marriage. Under the IMFA, when a citizen or LPR files a petition with the INS requesting residence for his immigrant spouse, and the qualifying marriage is less than two years old,${ }^{16}$ the INS awards the immigrant conditional residence. Under conditional residence, the marriage must remain intact for at least two years; otherwise, the immigrant spouse loses her legal status, and becomes deportable. Because an immigrant cannot petition for her own conditional status, battered wives can be trapped in something less than wedded bliss. In 1988, Congress amended the IMFA in an attempt to correct this problem by allowing women who could prove they were battered to adjust from conditional to legal permanent resident

with which to negotiate changes in their husbands' behavior. Thus marital dependency reinforces the likelihood that women will tolerate physical abuse from their husbands.

Debra S. Kalmuss \& Murray A. Straus, Wife's Marital Dependency and Wife Abuse in PHYSICAL VIOLENCE IN AMERICAN FAMILIES 369, 379 (Murray A. Straus \& Richard J. Gelles eds., 1990) [hereinafter PHYSICAL VIOLENCE].

Some psychologists embrace a theory of an abused woman's mental state called the "battered woman syndrome." In a pattern of learned helplessness, an individual, perceiving no correlation between her behavior and the abuse she sustains, may come to believe that she has little or no control in her life. Lenore E. Averbach, What Counselors Should Know about the Battered Woman, in THE MALE BATTERER: A TREATMENT APPROACH 158-160 (Daniel Jay Sonkin et al. eds., 1985) [hereinafter THE MALE BATTERER]. But the "battered women syndrome" cannot fully explain or adequately address the experience of many women of color. See, e.g., Sharon A. Allard, Rethinking Battered Woman Syndrome: A Black Feminist Perspective, 1 UCLA WOMEN's L.J. 191, 205, 206 (1991).

14. Migration places stress on families, which may increase the odds that a husband will act violently toward his spouse. See HOGELAND \& ROSEN, supra note 4, at 15-16; Jorge Banales, Riots Show Latino Immigrants' Alienation, UPI, May 7, 1991, available in LEXIS, Nexis Library, UPI File; Banales, supra note 4. These facts, of course, do not excuse battery; they simply shed light on why it happens.

15. Leslye Orloff, Domestic Violence Cases Involving Immigrant and Refugee Communities: The Response of the Courts, in Family Violence: Issues of Public Policy and Government Practice (forthcoming) (manuscript at 4 , on file with author) (noting that $52 \%$ of those women are still living with their abusive partners).

16. 8 C.F.R. $\$ 216.1$ (1992) (defining conditional resident as an "alien who has been lawfully admitted for permanent residence [as a spouse] ... subject to the conditions and responsibilities set forth ... in this chapter"). 
status. That amendment was too limited in scope, however, and too narrowly interpreted by the INS. Congress' original attempt to regulate marriage fraud and its legislative and regulatory progeny have thus inadvertently increased abusers' coercive power over conditional resident spouses.

Part I of this Note portrays difficulties facing certain immigrant women by describing two subpopulations of female conditional residents: military brides and so-called "mail-order brides." Part II describes the statutory and regulatory scheme governing immigrant women, including the IMFA of 1986 that Congress enacted to curb illegitimate immigration, ${ }^{17}$ the amendment to the statute in $1988,{ }^{18}$ and subsequent INS regulations implementing these laws. ${ }^{19}$ Part III argues that the current statutory and regulatory framework exacerbates immigrant women's dependence upon their spouses, establishes unreasonable evidentiary requirements, and ignores community barriers and immigrants' fear of bureaucratic entanglement. Part IV urges that we solve these problems by allowing women to petition for immigration status, establishing reasonable evidentiary requirements, and encouraging confident interaction with bureaucracy. ${ }^{20}$ Some proposed solutions would require only new INS regulations that conform with statutory intent, while others would require Congress to amend the present statutory scheme. Part V analyzes the likely impact of these proposed changes.

\section{Two SUBPopulations OF CONDITTONAL RESIDENTS}

Foreign nationals can come to marry U.S. citizens or LPR's in a variety of ways. For example, a citizen may live overseas for some time, marry, and then bring the spouse to the United States, as occasionally occurs with military wives. Sometimes foreign nationals and U.S. citizens or LPR's first come to know each other entirely through the mail, after which the foreign national immigrates and marries, as with many mail-order bride unions. In other circumstances, a foreign national enters the United States on a student, tourist, business, or other visa, marries, or simply remains in this country beyond his or her visa limits, and then weds a legal resident. Other immigrants reside in the United States illegally for some time and then marry citizens or LPR's.

Unique stresses can arise when two people from different cultures marry. Two types of intercultural relationships illustrate some reasons why immigrant women may be particularly susceptible to abuse in these circumstances: marriages involving military and mail-order brides. These conditional residents are not the only immigrant women at risk of battery. Their problems, however,

17. 8 U.S.C. $\S \S 1184(\mathrm{~d}), 1186 \mathrm{a}(1988)$.

18. 8 U.S.C. $\S 1186 a(c)(4)$ (1990 Supp. II).

19. 8 C.F.R. $\$ 216$ (1992).

20. On July 24, 1992, Representatives Mazzoli and Slaughter introduced a bill in Congress, H.R. 5693, to solve many of the problems I outline in this Note. Unfortunately, the bill did not pass. 
illustrate the power disparity and particular stresses that may operate in families in which conditional resident status applies.

\section{A. Military Brides}

Men stationed overseas in the armed forces may marry women born in foreign countries, sometimes referred to as "war brides." As a result of the deployment of U.S. troops in Asian countries, for example, over 200,000 Japanese, Vietnamese, Thai, Korean, and Filipino women have married U.S. servicemen and immigrated to the United States since World War $\mathrm{II}^{21}$

The frequency of abuse in military families is proportionally much greater than in civilian families. ${ }^{22}$ Various stresses associated with military life contribute to the increased risk of battery. The transient nature of military service increases social isolation, preventing family members from establishing roots in a community. ${ }^{23}$ Employment and financial pressures, as well as extended separation when active duty soldiers are stationed away from home, add pressure to these families' lives. ${ }^{24}$ Perhaps most significant, aggressive values indoctrinated into soldiers encourage them to use physical force to express displeasure when faced with domestic problems. ${ }^{25}$

The severity of domestic abuse in military families "makes the usual patterns of violence in civilian families pale by comparison."26 In one study, for instance, those employed in the military used weapons on their wives almost twice as often as civilian batterers, and "three-fourths of the military cases were in the dangerously life-endangering category compared to only about one-third of the civilian cases."27 Researchers have concluded that "[t]he worst of the civilian cases were the norm for the military cases."28 What is more, since military wives are traditionally expected to participate in and support their husbands' careers, thus playing a special role in the success

21. Teresa AmotT \& Julie Matthaei, Race, Gender \& Work: A Multicultural Economic HISTORY OF WOMEN IN THE UNITED STATES 253 (1991); BONNIE DEMROSE STONE \& BETTY SOWERS ALT, UNCLE SAM'S BRIDES: THE WORLD OF MILITARY WIVES, 128-29 (1990).

22. ANSON SHuPE ET AL., VIOLENT MEN, VIOLENT COUPLES: THE DYNAMiCS OF DOMESTIC VIOLENCE 70 (1987); STONE \& ALT, supra note 21, at 109.

23. SHUPE ET AL., supra note 22, at 67, 69; The Male Batterer: An Overview, in THE MALE BATTERER, supra note 13 , at 51 .

24. The Male Batterer: An Overview, in THE MALE BATTERER, supra note 13, at 51-52. For military wives, employment is difficult to obtain. See STONE \& ALT, supra note 21, at 151-58, 163 (stating that "unemployment rate for military wives is sometimes triple that of civilians").

25. SHUPE ET AL., supra note 22, at 67 (noting that heavy emphasis in military training on "masculinity and aggressiveness" has proven to be important component of male violence toward women in research on civilian couples as well); STONE \& ALT, supra note 21, at 110-111; The Male Batterer: An Overview, in THE MALE BATTERER, supra note 13, at 50.

26. SHUPE ET AL., supra note 22 , at 67.

27. Id. at $76,79$.

28. Id. at 77 . 
or failure of those careers, ${ }^{29}$ wives are generally reluctant to report spousal abuse to the military police or other authorities. ${ }^{30}$

These problems may be exacerbated for immigrant women. In addition to aggressive military indoctrination, cultural and linguistic differences between the partners can impede communication and increase frustration. ${ }^{31}$ Without the nearby support of family and friends, immigrant women are isolated in a foreign environment. ${ }^{32}$ Captain Nancy K. Raiha, an army social worker, explains:

In any intercultural marriage differences in norms, values, expectations, and habits may lead to tension and conflict. Social pressures (i.e. discrimination) are sometimes an additional burden to the interracial couple. .. . Couples who are unable to communicate verbally seem more likely in some cases to resort to physical means of expressing displeasure and frustration. ${ }^{33}$

These stresses on the military family relationship increase the risk that "men who already have a proclivity for acting out their anger" will do so. ${ }^{34}$

One woman's situation typifies the problems immigrants may face as military brides. Merta met her husband while he was stationed in Greece. They married and moved to Texas. Merta spoke little English. Her husband was obsessively jealous and controlling, and he forbade her to leave the house. Playing on her media-inspired image of the United States, he warned her that the outside world was a "death trap." She was forbidden to leave his side or speak to anyone, and he beat her routinely. Not long before she escaped the relationship, Merta's husband had won a "Sergeant of the Year" award. ${ }^{35}$

\section{B. Mail-Order Brides}

"Mail-order brides," women who are advertised in catalogs (the most popular of which is entitled Cherry Blossoms $)^{36}$ for marriage to American

29. Id. at 70.

30. Id. See also STONE \& ALT, supra note 21, at 106-07 (discussing career ramifications-from verbal reprimand to demotion to being declared unfit for service-of wife's report of domestic assault).

31. AMOTT \& MATTHAEI, supra note 21, at 253; STONE \& ALT, supra note 21, at 144; The Male Batterer: An Overview, in THE MALE BATTERER, supra note 13, at 51.

32. AMOTT \& MATTHAEI, supra note 21, at 253; The Male Batterer: An Overview, in THE MALE BATTERER, supra note 13, at 51; Venny Villapando, The Business of Selling Mail-Order Brides, in MAKING WAVES: AN ANTHOLOGY OF WRITING BY AND ABOUT ASIAN AMERICAN WOMEN 318, 319 (Asian Women United of Califormia ed., 1989).

33. SHUPE ET AL., supra note 22 , at 75.

34. The Male Batterer: An Overview, in THE MALE BATTERER, supra note 13, at 51.

35. SHUPE ET AL., supra note 22 , at 75.

36. The term "mail-order bride" may contribute to the conceptualization and treatment of Asian women as exotic, fungible commodities instead of individuals. Villapando, supra note 32, at 325; Charles McCue, She's No Suzy Wong, GANNET NEwS SERVICE, Apr. 22, 1991. 
men, generally come from destitute conditions in parts of Asia. ${ }^{37}$ Most are born in the Philippines, a country troubled by political strife and high unemployment. ${ }^{38}$ Over $70 \%$ of Philippine women live in poverty, thus making them particularly vulnerable to the mail-order industry. ${ }^{39}$

The mail-order bride business appears to be thriving. ${ }^{40}$ Approximately 200 companies operate in the United States ${ }^{41}$ and an estimated 2000 to 3500 American men find wives through these catalogs each year. ${ }^{42}$ In June 1990, the government of the Philippines, alarmed at reports of widespread abuse of Philippine women in other countries, outlawed bride agencies. That move simply drove the mail-order business underground without significantly affecting the international trade. ${ }^{43}$

Mail-order bride relationships begin when a company travels to the Philippines (or another economically troubled country) to recruit women for its catalogs. ${ }^{44}$ Bolstered by the promise of a glamorous life in the United States, ${ }^{45}$ the company convinces multitudes of young Philippine women ${ }^{46}$ to list themselves. Typically, an older American man, ${ }^{47}$ having become disenchanted with the changing gender roles of the past few decades, ${ }^{48}$ joins

37. HOGELAND \& ROSEN, supra note 4, at 7-8; Hodgin, supra note 4.

38. Hodgin, supra note 4.

39. HOGELAND \& ROSEN, supra note 4, at 7; see also Villapando, supra note 32 , at 322.

40. Hodgin, supra note 4 (noting that Nihonmachi Legal Outreach Center in San Francisco, an Asian immigrant advocacy group, has observed recent increase in the industry); James Leung, Many Mail-Order Brides Find Intimidation, Abuse: Marriages Made in China for U.S. Citizenship, S.F. CHRON., Sept. 4, 1990, at A9 (reporting that Chinese-language newspapers are full of advertisements for mail-order brides).

41. Melinda Henneberger, Well, the Ukraine Girls Really Knock Them Out, N.Y. TIMES, Nov. 15, 1992, at E6; see also Jon McKenna, How to Find Women 'Who Would Marry Dear Old Dad,' ATLANTA Bus. ChroN., Mar. 26, 1990, at A3 (estimating 50 mail-order bride businesses).

42. AMotT \& MATTHAEl, supra note 21, at 254; Cynthia Kadohata, More Than He Bargained For, N.Y. TIMES, Jan. 7, 1990, $\$ 7$ (Book Reviews), at 15; see also Henneberger, supra note 41 (reporting that in 1991, 100 mail-order brides immigrated to New York alone).

43. Philippines: Stops "Mail-Order Bride" Trade, INTER PRESS SERVICE, June 14, 1990, available in LEXIS, Nexis Library, Inter Press Service File. The law provides penalties of up to 8 years in prison and $\$ 1000$ in fines.

44. Philippine women comprise $87 \%$ of the women recently featured in a popular mail-order bride catalog. U.S.-ASIAN CONNECTION, PROMOTIONAL LETTER, Feb. 1993, at 1.

45. Villapando, supra note 32 , at 320-22.

46. A 19-year-old seeks "a lifetime partner aged 30-50," while a 17-year-old "seeks friends aged 30 and above." U.S.-ASIAN CONNECTION, PROMOTIONAL CATALOG, Oct. 1992, at 16. A 24-year-old seeks a "lifetime partner aged 25-60" Id., Feb. 1993, at 1. It is not unreasonable to assume that catalog companies coach young women to indicate a preference for older men-the catalogs' main customers. See infra note 47. Some females advertised are as young as 13 years old. Paul Watson, Mail-Order Bride Firms Flourish in Canada, Toronto STAR, Nov. 9, 1992, at A1.

47. Most men using the mail-order bride business are older and divorced. One industry brochure claims that " $a$ [] pleasant difference [between Philippine and American women] is [the former's] willingness to accept and often times their preference for older men. Many Filipinas prefer a man who is 5, 10, 20 or more years their senior. Many Asian cultures seem to have a great respect for older and wiser people." Marites LeWIS \& Steven LeWIS, How To Find a Beaumful, Faithful Asian Wife 16 (1991). Although the mail-order marriage industry claims that Asian women prefer to be much younger than their partners, a large age disparity can be a great source of stress in a relationship, and, thus, one factor associated with domestic assault. See, e.g., Wilson \& Daly, supra note 2, at 95 (discussing large age disparity between husband and wife associated with domestic homicide).

48. These men typically view the women's movement as the reason they cannot maintain satisfactory 
a mail-order bride club to find a "beautiful, faithful, Asian wife." company sends him a catalog with the pictures, vital statistics, and addresses of potential mates. The man usually conducts a mass mailing to women he finds appealing and continues to write to promising prospects, hoping to "woo" one into marriage. ${ }^{50}$ Alternatively, the industry encourages him to travel to the Philippines, mail-order catalogs in hand, to track down women using their listed addresses. ${ }^{51}$ Mail-order catalogs offer men scripts to use once in the

relationships with women. Henneberger, supra note 41 (stating that mail-order bride industry "was renewed, the brokers say, in the 1970's, when men who considered themselves casualties of the American women's movement began looking overseas for more traditional wives"). Promotional material for one mail-order bride catalog boasts a letter from a happily married "Marcus" who explains that, " $[I]$ t is easy to understand why so many European, Australian, and American men are going [to the Philippines] to select their wives. Unlike American women, most Filipinas are virgins up until the day they are married . . . Filipinas are more caring, loving, devoted to their husband \& children, understanding, and responsible than American women .... They have much more concern for the family unit and are against the idea of divorce." U.S.-ASIAN CONNECTION, PROMOTIONAL MATERIALS, Fall 1992 Update (claiming that the letter "is typical of the well over 200 confirmed marriages resulting from our service").

Such motivations appear to be shared internationally. One Canadian consumer of mail-order bride catalogs laments the "overly liberated North American females" by stating, "Filipino women still have a lot of the old traditions in them, eh? ... They walk behind you where Canadian girls walk all over you." A Canadian mail-order bride publisher notes that "[t]his female liberation has done a lot for the females, but it sure hasn't done much for the fellow who's looking for a wife." Watson, supra note 46. In Japan, where some 20,000 mail-order brides immigrated over the last five years, "non-Japanese Asian women are popular with Japanese men because they are considered easier to control than their Japanese counterparts." Suvendrini Kakuchi, Japan: Landmark Court Ruling Upholds Rights of 'Mail Order' Brides, INTER PRESS SERVICE, Feb. 21, 1991, available in LEXIS, Nexis Library, Inter Press Service File. In Australia, where one report claims that $20 \%$ of the immigrant women marrying Australian residents are Philippine, many men choose mail-order brides because of a "stereotypical image . . . of Filipino women as being domesticated and subservient." Kalinga Seneviratne, Australia: Filipino Mail Order Brides End Up Being Murdered, INTER PRESS SERvICE, July 20, 1991, available in LEXIS, Nexis Library, Inter Press Service File.

Abuse of mail-order brides is common in other countries, as well. In the past few years, for example, there have been 11 officially acknowledged cases of Australian husbands murdering their Philippine mail-order brides. Id.

49. See generally LEWIS \& LEWIS, supra note 47. Both "mail-order brides" and their browsing "grooms" are tutored in how to discover and obtain the ideal mate. Catalog companies laud the obsequiousness "inherently natural in an Oriental." Watson, supra note 46. And where what is "natural" for an "Oriental" leaves off, the mail-order bride industry picks up. Catalog publishers coach women in deferential mannerisms to please potential mates. Villapando, supra note 32 , at $318-19,322$. The stereotype of the geisha girl is not shattered until the marriage is consummated. McCue, supra note 36 . Women are described in catalogs as "likes to cook," "likes to sew," "likes home," "likes to keep house," or "enjoys household chores." U.S.-AsIAN CONNECTION, PROMOTIONAL CATALOG, Oct. 1992, at 16. In contrast, in a new "Russian ladies" catalog, the women express such interests as "enjoys psychology, art, travel, and nature." One company affords Russian women, unlike Philippine women, an opportunity to describe their "ideal man." One woman indicated that her ideal would be "age 25-35; courageous, prosperous, blond and sports minded;" another wanted someone "educated, clever and kind." U.S.-ASIAN CONNECTION, RUSSIAN Promotional Catalog, Feb. 1993, at 2.

50. Men are instructed in various wooing techniques, including the "shotgun approach" whereby a browser performs a mass mailing of photocopied letters to numerous women indicating his interest in them; a sample letter is provided, and men are told to employ generic greetings, such as "Dear Pretty Lady." LEWIS \& LEWIS, supra note 47, at 8; Henneberger, supra note 41 (noting that "the purveyors of marital bliss suggest that volume is the key to finding a match"). For a bit extra, a man can pay the company to do the time-consuming business of letter-writing or gift-buying to woo prospective mates. Villapando, supra note 32, at 320-21. Some companies will write a man's personals ad as well; see U.S.-ASIAN CONNECTION, ORDER FORM, 1993 ("We can compose your ad for you if you would prefer.").

51. The industry encourages: "With 100's of young ladies in each of your issues you really have almost unlimited possibilities." An efficient method of pursuing the women once in the Philippines, one 
presence of these women. If all else fails, one publisher explains, a man must be a "beast type." "If she can't be taken by [more subtle] tactics, use speed and force," he writes. ${ }^{52}$ "As it is said, action is better than words. But I say 'action with the combination of words are the best.' But be careful because you might be charged with rape and risk your reputation." ${ }^{253}$

When these cross-cultural interchanges do result in marriage, unrealistic expectations on both sides often mean severe incompatibility at best, and outright abuse at worst. ${ }^{54}$ As Carmencita Hernandez, Chair of the Women's Committee of the National Council of Canadian-Filipino Associations, explains, "[w] hen a Filipino woman-who is stereotyped as meek-stands up for herself, the trouble begins." ${ }^{55}$ In one case, a twenty-two-year-old woman named Ngan married a U.S. citizen and immigrated to this country. Ngan was not the picture bride her husband believed he had ordered. "The first time he beat me, I was too afraid to do anything about it," she said. The second assault drew blood. Her neighbors took her to the hospital, and then to an Asian battered women's shelter. ${ }^{56}$

The story of a twenty-four-year-old woman named Raco offers another example. Raco married a U.S. citizen who had courted her by mail for ten years. Soon after she came to this country, he began to beat her because of differences she had with his parents. His assaults worsened because she did not want to bear children immediately. When she became pregnant, "[h]e threatened not to sponsor me for permanent residence if I didn't carry the pregnancy to term," she said. But the violence escalated, even after she decided to have the baby. ${ }^{57}$ When she was six-months pregnant, he beat her

company urges, is to hire a taxicab driver and "just relax in the . . a air conditioned hotels" while the cab driver "battle[s] the traffic and heat" to locate women. "The worst that could happen is that the young lady could tell the cab driver that she is already engaged or married. The cab driver could simply cross off her name and go find the next young lady on your list." LEwIS \& LEwIS, supra note 47 , at 30 . Some Australian men have taken to importing multiple fiancees on short visas and then sending them back when their visas expire, only to sponsor another. Australian welfare workers report that many Australian men boast that it is "cheaper to get an Asian wife than to get an Australian prostitute." Seneviratne, supra note 48.

52. Watson, supra note 46.

53. Id.

54. Villapando, supra note 32 , at $\mathbf{3 2 5 .}$

55. Filipino Canadians Urged to Speak Up about Abuse, GAZETTE (MONTREAL), Feb. 23, 1992, at A3; see also Henneberger, supra note 41 ("The exotic charm of a distant correspondent can fade abruptly in the reality of culture shock and life with a stranger. Many of the prospective brides end up being deported. And the women, who are often quite young and speak little English, also risk isolation and abandonment if not outright abuse from men they have known only through letters.").

56. Leung, Many Mail-Order Brides Find Intimidation, Abuse: Marriages Made in China for U.S. Citizenship, supra note 40 , at A9.

57. Studies have shown that abusive husbands become more violent when their partners become pregnant. Richard J. Gelles, Violence and Pregnancy: Are Pregnant Women at Greater Risk of Abuse? in PHYSICAL VIOLENCE, supra note 13, at 282-83 ("Pregnant women's risk of abusive violence was $60.6 \%$ greater than that of nonpregnant women, while the overall risk of any form of violence to pregnant women was $35.6 \%$ greater than that of nonpregnant women. Not only did pregnant women report higher rates of violence, but men with pregnant wives or partners reported that they were more violent to their partners than were men married to women who were not pregnant at the time of the interview."); see also Diane Bohn, Domestic Violence and Pregnancy, 35 J. NURSE-MIDWIFERY 86, 88-91 (1990); Judith McFarlane, 
so fiercely that she feared for the life of her unborn child and fled to a shelter. ${ }^{58}$

What mail-order brides such as Ngan and Raco have in common with military wives such as Merta is that they are all conditional residents. They face the problems of a statutory framework that gives much of the control over their immigration status to their abusive spouses.

\section{THE STATUTORY AND REgULATORY FRAMEWORK}

The statutory scheme of conditional residency that affects Ngan, Raco, and Merta consists of two major legislative acts-the Immigration Marriage Fraud Amendments (IMFA) of 1986 and a battered-spouse amendment to the IMFA of 1988-and subsequent INS regulations implementing those acts.

\section{A. The Immigration Marriage Fraud Amendments (IMFA)}

After the 1952 Immigration and Nationality Act, an alien who married a U.S. citizen or LPR could adjust his or her immigration status and become a legal permanent resident without leaving the country. ${ }^{59}$ In recent years, however, legislators have become concerned about incidents of "marriage fraud" in which a foreign national marries a citizen or LPR for the sole purpose of obtaining legal immigration status. Believing that a "tide" of foreign-born persons was gaining legal status in this country through dubious marriages, ${ }^{60}$ Congress passed the IMFA of $1986,{ }^{61}$ which created a series of

Battering During Pregnancy: Tip of an Iceberg Revealed, 15 WOMEN \& HEALTH 69, 71-72 (1989).

58. Marvine Howe, Battered Alien Spouses Find a Way to Escape an Immigration Trap, N.Y. TIMES, Aug. 25, 1991, at A40.

59. 8 U.S.C. $\$ 1101(a)(15)$ (1988). Before 1952, an alien had to depart the country and apply to consular officials to obtain legal permanent residence. Linda Bird Francke, The Mating Game, NEWSWEEK, Jan. 19,1976 , at 48 .

60. See Arthur F. Corwin. The Numbers Game: Estimates of Illegal Aliens in the United States, 1970-1981, 45 LAW \& CONTEMP. PROBS. 223 (1982); Joe A. Tucker, Assimilation to the United States: A Study of the Adjustment of Status and the Immigration Marriage Fraud Statutes, 7 YALE L. \& POL'Y REV. 20, 28-29 (1989) (explaining that both Immigration Reform and Control Act and Marriage Fraud Act were based on highly speculative assertions of a "rising tide of illegal[s]"); Karen L. Rae, Comment, Alienating Sham Marriages for Tougher Immigration Penalties: Congress Enacts the Marriage Fraud Act, 15 PEPP. L. REV. 181, 182-83, n.17 (1988) (citing articles discussing "sham marriages" as "the most popular ploy ... to beat the immigration system"); Note, The Constitutionality of the INS Sham Marriage Investigation Policy, 99 HARV. L. REV. 1238, 1241 n.20 (1986) (citing interview with Senator Alan Simpson concerning magnitude of sham marriage problem).

A brief consideration of who defrauds whom in "sham marriages" clarifies the dynamics of marriage fraud. In some cases, the foreign national defrauds both the citizen and the INS in an effort to gain legal status in the United States. Single citizen women with children are particularly susceptible to this tactic. See Tucker, supra, at 32-33; Andree Brooks, Single Mothers Are the Targets in Marriage Fraud, N.Y. TIMES, June 13, 1985, at Cl. In other instances, the citizen or LPR conspires with the alien to defraud the INS. See Francke, supra note 59; Bob Reiss, The Melting Plot: Grooming for the Green Card with Money-Order Brides, WaSH. PoST, July 17, 1977, Magazine, at 12.

The exact figures on the incidence of marriage fraud are difficult to determine. In the past, the INS has asserted a $30 \%$ fraud rate between foreign nationals and U.S. citizens or LPR's. Immigration Marriage 
legal encumbrances for those wishing to marry foreign nationals. The IMFA was passed four days after a larger immigration law package called the Immigration Reform and Control Act (IRCA) of $1986 .^{62}$

The IMFA, which primarily burdened female immigrants, changed the status of aliens who marry citizens or LPR's. ${ }^{63}$ Before the IMFA, when a U.S. citizen or LPR who married a foreign national petitioned for his immigrant spouse, she was afforded permanent residency. ${ }^{64}$ Emboldened by a cross-national survey called "Immigration Marriage Fraud: Controls in Most Countries Surveyed Stronger than in U.S.," which found that seven out of twelve countries surveyed had a revokable conditional resident status bestowed on all noncitizens who married citizens, Congress passed the IMFA to require that a citizen or LPR spouse petition for the "conditional" resident status of his immigrant spouse. ${ }^{65}$ The conditional period commenced on the date the immigrant obtained conditional status, not at the beginning of the marriage. ${ }^{66}$ After the INS granted the immigrant conditional resident status, the law mandated that conditional status last for a period of at least two years, during which time the couple must remain married. ${ }^{67}$ Administrative delays in visa processing meant that an immigrant's conditional status could continue for four years, or more. ${ }^{68}$ If the marriage dissolved at any time during the conditional residency, the immigrant lost conditional status in this country and became a deportable illegal alien. ${ }^{69}$

Fraud, Hearings on S.521-15 before the Subcomm. on Immigration and Refugee Policy of the Senate Comm. on the Judiciary, 99th Cong., 1st Sess. 35 (1985) [hereinafter Fraud Hearings] (statement of INS Commissioner Alan C. Nelson); Marriage Fraud Amendment Regulations, 53 Fed. Reg. 2426 (Jan. 27, 1988). Today, however, the INS asserts that the rate of marriage fraud is closer to $8 \%$. The INS contends that the rate of marriage fraud in the greater Los Angeles area, which it estimates at $15 \%$, is one of the highest in the United States. Tammerlin Drummond, Green Card: Real Life Drama Is a Cat and Mouse Game, L.A. TimES, Apr. 21, 1991, at A3. However, the INS figures are of questionable reliability. INS Reveals Basis for Fraud Claims, 65 INTERPRETER RELEASES 26 (1988) (explaining that extremely small (one-twentieth of one percent), nonrandom statistical sample was employed, rendering any conclusions speculative); Fraud Hearings, supra, at 88 (statement of Jules E. Covan, President of the American Immigration Lawyers Association).

61. Pub. L. No. 99-639, 100 Stat. 3537 (codified at 8 U.S.C. \$§ 1184(d), 1186a (1988)).

62. Pub. L. No. 99-603, 100 Stat. 3359 (1986) (codified in scattered sections of 8 U.S.C.).

63. Tucker calls the IMFA "an appalling attempt to conserve administrative resources at the cost of "human capital." Tucker, supra note 60, at 50, 94; see also William Tamayo, The Evolution of United States Immigration Policy, in DOMESTIC VIOLENCE, supra note 4, at IV-7, 8.

64. Marriage Fraud Amendment Regulations, 53 Fed. Reg. 2426 (1988) (citing history of "permitting immediate family members of United States citizens to immigrate to the United States without numerical limitation").

65. 8 U.S.C. \& 1186a(a)(1) (1988).

66. 8 U.S.C. \$ 1186a(a)(2) (1988); see also INS Issues Further Instructions on Immigration Marriage Fraud Law, 63 INTERPRETER RELEASES 1076, 1077 (1986) [hereinafter INS Issues Instructions].

67. 8 U.S.C. $\$ 1186 \mathrm{a}(\mathrm{g})(1988)$.

68. Tucker, supra note 60 , at 35 .

69. 8 U.S.C. $\$ \S 1186 a(b)(1)$, (2) (1988) ("II]f the Attorney General determines, before the second anniversary of the alien's obtaining the status of lawful admission for [conditional] permanent residence, that ... the qualifying marriage ... has been judicially annulled or terminated ... the Attorney General ... shall terminate the [conditional] permanent resident status of the alien (or aliens) involved ... ."); see also Matter of Lehammad, No. A-27935756, Interim Decision 3150, 1991 B.I.A. LEXIS 13 (holding that the burden is on the INS to prove by a preponderance of the evidence that one of the conditions of 
Once the INS granted conditional status, an immigrant became locked in a narrow procedural corridor. She qualified for legal permanent residence only if she and her spouse jointly petitioned the INS before the end of two years to adjust her conditional status to permanent residence. Both partners had to participate in a personal interview with the INS. ${ }^{70}$ All other options for an immigrant to gain legal status evaporated; as a conditional resident she could not adjust her immigration status on any other statutory grounds. ${ }^{71}$ Consequently, in most cases, her ability to remain legally in the United States depended exclusively on the goodwill of her husband and the continued viability of her marriage. ${ }^{72}$

Under the IMFA, the INS waived the joint petition requirement only in rare cases: the death of the citizen spouse, the showing of good-cause termination, or the showing of extreme hardship from deportation. ${ }^{73}$ For a divorced conditional resident to obtain a good-cause waiver to the joint petition phase of the process, she had to demonstrate that she entered the marriage in good faith and that she initiated divorce proceedings for "good cause."74 The regulations did not indicate whether or not spousal abuse qualified as "good cause." 75 Further, divorce proceedings in "no-fault" divorce states such as California produced little evidence to support a claim of "good cause."76

Alternatively, a conditional resident must prove that deportation would subject her to "extreme hardship" resulting from circumstances that arose during her two-year conditional residence. ${ }^{77}$ Such a showing is difficult to make, particularly since the INS is unlikely to find extreme hardship except in rare cases. ${ }^{78}$ Battering by one's spouse in this country would not qualify one for this kind of waiver because extreme hardship from deportation, not the extreme hardship one endures in a marriage, is what is at issue. ${ }^{79}$

termination has been met).

70. 8 U.S.C. $\S \S 1186 a(c)$, (d) (1988).

71. 8 U.S.C. $\$ 1255$ (d) (1988); 53 Fed. Reg. 2426 (1988); INS Issues Instructions, supra note 66, at 1079. A foreign national whose conditional status has been terminated, however, may seek relief from deportation. See Matter of Stockwell, No. A-28541697, Interim Decision 3150, 1991 B.I.A. LEXIS 11 (holding that Immigration and Nationality Act does not prohibit alien whose conditional status has been terminated from adjusting her status).

72. Tucker, supra note 60 , at 29.

73. 8 U.S.C. $\S \S 1186 \mathrm{a}(\mathrm{c})(1)$, (c)(4) (1988). A waiver adjusts one's conditional status to permanent resident status.

74. 8 U.S.C. $\$ 1186 \mathrm{a}(\mathrm{c})(4)(\mathrm{B})(1988)$.

75. Tucker, supra note 60 , at 38 . Good cause is "used in the regulation in accordance with [its] everyday meaning." 53 Fed. Reg. 30,015 (1988).

76. Tucker, supra note 60 , at 38 ; Fellom, supra note 4.

77. 8 U.S.C. $\$ 1186$ (c)(4)(A) (1988) ("In determining extreme hardship, the Attorney General shall consider circumstances occurring only during the period that the alien was admitted for permanent residence on a conditional basis.").

78. INS v. Wang, 450 U.S. 139, 145 (1981) ("The Attorney General and his delegates have the authority to construe "extreme hardship' narrowly"); Hernandez-Patino v. INS, 831 F.2d 750, 754-55 (7th Cir. 1987) (holding that economic deprivation, lack of family assistance and denial of special education for disabled children do not constitute extreme hardship for relief from deportation).

79. Letter from Bonnie Derwinski, INS Director of Congressional and Public Affairs, to the Honorable 


\section{B. The Immigration Act of 1990}

On September 27, 1989, the House Judiciary Committee on Immigration, Refugees and International Law held a hearing on the domestic violence occurring in marriages between immigrants and American citizens. Representative Louise M. Slaughter described the abuse of one conditional resident in Rochester, New York who sought her help ${ }^{80}$ and her own dismay when, "Once we looked into her legal options, we realized she had none."

To remedy this dilemma, Representative Slaughter introduced a bill in the House called the Marriage Fraud Amendments Act of $1989 .{ }^{82}$ Representative Bruce Morrison included a version of this bill in $\S 701$ of his comprehensive immigration legislation which passed in November 29, 1990 and became the Immigration Act of $1990 .{ }^{83}$ The legislation's purpose was to provide that both battery and extreme cruelty could qualify an immigrant for a waiver of conditional status whenever, during the two-year period, it is alleged and proven. The amended law states that, if a conditional resident demonstrates that "the qualifying marriage was entered into in good faith by the alien spouse" and that "the alien spouse or child was battered by or was the subject of extreme cruelty perpetrated by his or her spouse," then the limitations of conditional resident status are removed and the foreign-born spouse is granted permanent legal resident status. ${ }^{84}$

This legislation also eliminated the good cause waiver and provided a waiver based on the termination of a good faith marriage without regard to who initiated the divorce or the reason for the divorce. ${ }^{85}$ Desiring that the law cease to be an instrument by which immigrant women were victimized, Representative Slaughter said she hoped the legislation would provide immigrant spouses "an escape from beatings, insults and fear." 86

Louise Slaughter (Oct. 19, 1989), reprinted in 66 INTERPRETER RELEASES 1428 (1989).

80. 136 CONG. REC. H8642 (daily ed. Oct. 2, 1990) (statement of Rep. Slaughter) (describing Haitian woman married to American man who regularly beat her and "subjected [her] to unspeakable cruelties").

81. Telephone Interview with Sandra Sobieraj, Legislative Assistant to The Honorable Louise M. Slaughter, Member of Congress (April 3, 1992) [hereinafter Sobieraj Interview]. There was little lobbying on either side in committee. Id.

82. Pub. L. No. $99-639,100$ Stat. 3537.

83. Pub. L. No. 101-649, 104 Stat. 4978. Section 701 of the Immigration Act of 1990 amends $\S 216(\mathrm{c})(4)$ of the Immigration and Nationality Act, 8 U.S.C. $\S 1186 \mathrm{a}(\mathrm{c})(4)$ (1988).

84. 8 U.S.C. $\& 1186 \mathrm{a}(\mathrm{c})(4)(C)$ (Supp. II 1990). The House Judiciary Committee Report states, "The Committee notes that discretion given to the Attorney General to decide to deny waiver requests under this provision is to be limited to rare and exceptional circumstances such as when an alien poses a clear and significant detriment to the national interest." HoUSE JUDICIARY COMM., Family Unity and Employment Opportunity Immigration Act of 1990, No. 723, 101st Cong., 2d Sess., pt. 1, at 79 (1990).

85. 8 U.S.C. $\$ 1186 \mathrm{a}(\mathrm{c})(4)(B)$ (1990 Supp. II).

86. Howe, supra note 58 . 


\section{The INS Regulations}

On May 16, 1991, the INS published "interim" rules ${ }^{87}$ amending the conditional residence regulations to implement the new legislation. ${ }^{88}$ The rules established standards by which immigration officers were to process claims for battered-spouse waivers for adjustment of conditional to permanent status. The INS separated the waiver exception into two spheres: physical battery and extreme mental cruelty. ${ }^{89}$ Under the new rules, battered spouses are required to prove abuse by providing the INS with certain types of evidence. Proof of physical battery may include "expert testimony in the form of reports and affidavits from police, judges, medical personnel, school officials and social service agency personnel." $"$ The regulations mandate that the INS "must be satisfied with the credibility of the sources of documentation submitted in support of the application." 91

Documentation requirements for claims of extreme mental cruelty are more stringent. The regulations assert that the INS "is not in a position to evaluate testimony regarding a claim of extreme mental cruelty provided by unlicensed or untrained individuals." ${ }^{22}$ Thus, waiver applications based on extreme mental cruelty "must be supported by the evaluation of a professional recognized by the Service as an expert in the field." The only professionals recognized by the INS for the purpose of obtaining extreme mental cruelty waivers are "[1]icensed clinical social workers, psychologists, and

87. Conditional Basis of Lawful Permanent Residence for Certain Alien Spouses and Sons and Daughters; Battered and Abused Conditional Residents, 56 Fed. Reg. 22,635 (1991). The "interim" rule implemented $\$ 701$ of the Immigration Act of 1990. Id. The INS requested written comments by June 17, 1991. No sunset provision was written into the rule. For a discussion of the written response, see infra text accompanying notes 96-100. The "interim" rule was codified at 8 C.F.R. $\$ 216.5$ (1992). The INS has not indicated that it is planning to promulgate new rules to replace the "interim" rules-which have been fully promulgated. "Immediate implementation of this interim rule is necessary because the changes have been mandated by the passage of Pub. L. 101-649 . . Early implementation will allow qualified conditional residents to immediately apply for waivers . . . " Conditional Basis of Lawful Permanent Residence for Certain Alien Spouses and Sons and Daughters, 56 Fed. Reg. 22,635, 22,637 (1991).

88. Conditional Basis of Lawful Permanent Residence Status for Certain Alien Spouses and Sons and Daughters, 8 C.F.R. $\$ 216$ (1992). The Attomey General, and, by delegation, the Commissioner of the INS, have the power to "establish such regulations ... as [the Attomey General] deems necessary for carrying out his authority under the provisions of" Chapter 12, "Immigration and Nationality," of Title 8. 8 U.S.C. $\S 1103$ (1988). This authority includes "the administration and enforcement" of the Chapter. Id.

89. 8 C.F.R. $\S 216.5(\mathrm{e})(3)(\mathrm{i})(1992)$ (indicating that waiver covers "being the victim of any act or threatened act of violence, including any forceful detention, which results or threatens to result in physical or mental injury. Psychological or sexual abuse or exploitation, including rape, molestation, incest ... or forced prostitution shall be considered acts of violence.").

90. 8 C.F.R. $\S 216.5(\mathrm{e})(3)(\mathrm{iii})(1992)$.

91. Id.

92. 8 C.F.R. $\S 216.5(\mathrm{e})(3)(\mathrm{iv})(1992)$.

93. Id. The regulations require that "[t]he evaluation must contain the professional's full name, professional address, and license number. It must also identify the licensing, certifying, or registering authority." 8 C.F.R. $\$ 216.5(\mathrm{e})(3)(v)(1992)$. 
psychiatrists." ${ }^{\text {"Th }}$ The INS reserves the right to "request additional evaluations from expert witnesses chosen by the Service." 95

The INS received 180 written responses ${ }^{96}$ to the interim rules during the month-long public comment period of May 16 to June 17, 1991.97 Most of those responses were from agencies serving battered women and immigrants. ${ }^{98}$ Every written response to the regulations opposed the evidentiary requirements for proving mental cruelty, and nearly half of them objected to the evidentiary requirements for proving physical assault. ${ }^{99}$ Not one of the 180 responses supported the rules as they were written. ${ }^{100}$ These letters primarily criticized the way in which the INS rules curtailed the intended benefits of the battered-spouse waiver to the IMFA requirements.

\section{PROBlems WITH THE StatuTORY AND REgUlatoRy FramewORK}

Although Congress attempted to alleviate the suffering of abused immigrant women through the Immigration Act of 1990, the legislation was flawed and incomplete. Unfortunately, the subsequent INS regulations have made the situation worse. The current statutory and regulatory framework-the IMFA of 1986, the Immigration Act of 1990, and the INS regulations-allows husbands to control the petitioning process for women who have not yet obtained conditional status, establishes evidentiary requirements for adjusting from conditional to permanent status that the vast majority of immigrant women can never hope to meet, and ignores the community barriers facing immigrant women as well as immigrants' fear of bureaucratic entanglement.

\section{A. Husbands' Control Over the Initial Petitioning Process}

Under the current regulatory framework, a citizen or LPR must petition the INS to establish the legal conditional residence of his immigrant spouse in situations where the marriage is less than two years old. After the two-year conditional residency, a citizen or LPR must join the immigrant in petitioning

\footnotetext{
94. 8 C.F.R. $\$ 216.5(\mathrm{e})(3)(\mathrm{vii})(1992)$.

95. 8 C.F.R. $\$ 216.5(\mathrm{e})(3)(\mathrm{vi})(1992)$. After the immigrant has already paid for the first professional evaluation (assuming she can), it is not clear who would pay for these additional evaluations.

96. Telephone Interview with Rita Boie, Senior Immigration Examiner, INS (Mar. 9, 1992). Many were joint letters (e.g., the Asian Women's Shelter in San Francisco and the Asian Law Caucus together filed a letter to the INS). Telephone Interview with Beckie Masaki, Executive Director, Asian Women's Shelter of San Francisco, Calif. (Mar. 9, 1992) [hereinafter Masaki Interview]. The Network for the Rights of Immigrant Women, the American Immigration Lawyers Association, and the National Battered Women's Law Project also wrote a joint letter to the INS. Letter from Network for the Rights of Immigrant Women et al. to Patricia Cole, Assistant General Counsel, INS (April 24, 1991) (on file with author).

97. Conditional Basis of Lawful Permanent Residence for Certain Alien Spouses and Sons and Daughters; Battered and Abused Conditional Residents, 56 Fed. Reg. 22,635 (1991).

98. Boie, supra note 96.

99. Id.

100. Id.
} 
the INS to adjust her conditional status to permanent residence. This allows a batterer to coerce his immigrant spouse at two points in the process: 1) before he has ever petitioned the INS for the conditional residency of his immigrant wife, and 2) after he has petitioned for her conditional status, but before he agrees to petition jointly to adjust her conditional status to permanent status. Because the battered-spouse waiver of the Immigration Act of 1990 applies only to those already having conditional status, it attempts to eliminate the potential coercion only in the latter cases.

The legislation and subsequent regulations thus fail to respond to the abuse of what is likely the larger population of battered women-those immigrants whose husbands never filed petitions for their legal status. ${ }^{101}$ Such women simply "fall through the cracks." ${ }^{102}$ Thus, the battered-spouse waiver does not assist all abused immigrant women. It assists only those whose husbands have already petitioned the INS for their conditional status.

Furthermore, delay tactics can prolong a batterer's coercion over his spouse. Unless they can petition for conditional or permanent status themselves, immigrant women can be trapped in abusive relationships for an indefinite number of years. ${ }^{103}$

\section{B. Unreasonable Evidentiary Requirements}

The INS will not accept credible, personal affidavits as adequate proof of extreme mental cruelty (even if such statements are substantiated by other, nonprofessional affidavits). ${ }^{104}$ Thus, the INS regulations arguably create an

101. Lee Interview, supra note 9. The Family Violence Prevention Fund raised this issue with Representative Louise Slaughter, but she felt that the political climate was not sympathetic to these concerns. Id; see also HOGELAND \& ROSEN, supra note 4, at 15; Orloff, supra note 15, at 6.

102. Masaki Interview, supra note 96. Chris Hogeland, Immigrant Women in United States History in DOMESTIC VIOLENCE, supra note 4, at V-19.

103. Ignatius Bau et al., Immigration Marriage Fraud Amendments of 1986 (Marriage Fraud Act) and Other Related Issues, in DOMESTIC VIOLENCE, supra note 4, at VII-3; HOGELAND \& ROSEN, supra note 4 , at 16.

104. To justify the regulations' professional evaluation requirement, INS officials reported that they "consulted" with Dan Byrne, Deputy Director of the House of Ruth, a battered women's shelter in Washington, D.C., who "indicated that most social "help' agencies have a clinical social worker on staff." Based on this information, the INS stated that "we believe the conditional resident spouse or parent, friends, relatives, and others acting in their behalf, will have access to one or another of these professionals to obtain the evaluation required for substantiating a claim of mental or emotional abuse." Letter from Bonnie Derwinski, Director of Congressional and Public Affairs, INS, to The Honorable Louise Slaughter, Member of Congress, 2-3 (Apr. 29, 1991) (on file with author) [hereinafter April Derwinski Letter]. Dan Byrne denies that most social help agencies have licensed professionals on staff. Telephone Interview with Dan Byme, Deputy Director, House of Ruth (April 6, 1992) [hereinafter Byme Interview] ("We are particularly lucky, here at the House of Ruth, to have licensed clinical social workers on staff."). Moreover, Byrne notes, "The point I was trying to make to the INS is that immigrant women accessing a shelter 'present' a lot better than they are. They may appear to be fine, while in reality they may not be functioning well, and a trained professional can elicit the kind of information that would form an assessment of a woman's true mental health." The fact that women generally tend to hide their mental abuse, however, is not a reason for requiring professional testimony; it is a reason to grant waivers to those who do evince mental abuse. See also Debbie Lee, Identifying Battered Women, in DOMESTIC VIOLENCE, supra note 4, at II-8. Far from 
"impossibly high standard of proof."105 Immigrant women usually do not turn to the mental health professionals or to the counselors needed to prove mental cruelty. ${ }^{106}$ Indications are that many cannot. A survey of the psychiatrists, psychologists, and clinical social workers in the entire Los Angeles area, which has one of the largest concentrations of immigrants in the United States, revealed that there were "very few" bilingual professionals available. Of those available, most were private and would not evaluate clients without charge. ${ }^{107}$ Without resources to pay for a translator or social workers, psychiatrists, or psychologists, ${ }^{108}$ an abused immigrant cannot prove extreme mental cruelty. ${ }^{109}$ Moreover, the evidence required to establish extreme

being satisfied with the present resources available to immigrant women, Mr. Byrne, like others who work for battered immigrant women, emphasizes the need for training of counselors and other staff at social service agencies to make them more culturally competent. Byrne Interview, supra. See also HOGELAND \& ROSEN, supra note 4, at 23; Orloff, supra note 15 , at 10 (discussing need for bilingual and bicultural staff in social service agencies).

105. Lin, supra note 9 (quoting Martha F. Davis, staff attomey, NOW Legal Defense and Education Fund, as asserting, "Women may not leave abusive relationships because of this high burden of proof. . .. The result is that abused immigrant women are in the same position as they were in before."); Letter from Estelle Chun, Deputy Director, Asian Pacific American Legal Center, to Richard Sloan, Director of Policy Directives and Instructions Branch, INS 1, 3 (June 13, 1991) (on file with author) (hereinafter Chun Letter]. The INS has responded to the concerns about community barriers and burdens of proof by stating, "There has to be some standard. The INS is made up of people who are schooled in immigration law. We have no doctors or psychologists. We can't make a determination of mental abuse." April Derwinski Letter, supra note 104, at 2 . See also id. "The Service does not believe it would be possible to provide Service employees with training which would allow their judgment to be substituted for that of professionals with years of academic and practical experience in communicating with and evaluating the emotional condition of victims of mental cruelty.").

106. See Ignatius Bau et al., Immigration Marriage Fraud Amendments of 1986 (Marriage Fraud Act) and Other Related Issues, in DOMESTIC VIOLENCE, supra note 4, at VII-4; Chun Interview, supra note 12 ("When I saw the rule about extreme mental cruelty, I had to laugh."). There may be problems with the standard of proof for battery, as well. Unlike most people born in this country, many immigrant women do not use police, doctors, or shelters. Banales, supra note 4 (quoting expert asserting that "[s]ome aspects of the services available are not always acceptable for Third World people"); Lin, supra note 9, at 21 ("Pat Eng, managing director of the New York Asian Women's Shelter, says that while the INS may consider police complaints, doctors reports and health records as proof, "a lot of immigrant women may not use these facilities."'). Many immigrant women seek support elsewhere, such as from friends, family, neighbors, or clergy. If a woman does not go to a doctor or cannot afford one, she will not have a medical report to help prove the injuries she suffered at the hands of her batterer. See Orloff, supra note 15, at 6-7 (reporting statistics on immigrant women's poverty). If a woman does not call the police when she is assaulted, or police do not respond, she will not have police records to help prove that she was battered. Id. at 6 (citing study in which "[o]nly six of 304 [battered immigrant] women reported ever calling the police.").

107. Chun Letter, supra note 105, at 3 ("[T]here are only 8 licensed clinical psychiatrists, 7 licensed clinical psychologists and 23 licensed clinical social workers who target the Asian and Pacific Islander community. The language capabilities of most of these professionals are limited to the five major Asian Pacific groups .... . There are few, if any, licensed bilingual workers for a dozen or more smaller Asian Pacific subgroups (e.g., Cambodian, Samoan and Thai)."). See also HogelaND \& RoSEN, supra note 4, at 19 (31\% of Latinas reported that lack of bilingual services was central barrier to their utilizing social services).

108. "From my ten years of experience doing family law at Greater Boston Legal Services I know of not one battered woman who could have afforded to pay for even one interview with a clinical social worker, let alone a psychiatrist or psychologist. I probably represented over one thousand battered women, and I supervised a number of lawyers, students and paralegals whose experience was similar." Letter from Joan Zorza, Senior Attorney, National Battered Women's Law Project, to Gene McNary, Commissioner, INS 2 (May 13, 1991) (on file with author).

109. The standards for obtaining temporary restraining orders against batterers are much easier for women to meet. See Letter from The Honorable Louise M. Slaughter, Member of Congress, to Gene 
mental cruelty focuses entirely on the mental state of the victim, rather than on the actions of the abuser. A resilient woman who does not clinically evince the debilitating effects of psychological cruelty may not be able to obtain a waiver, even if she deserves one based on the level of abuse she sustains.

In addition to being excessive for immigrant women, the mental cruelty evidentiary requirement may be inconsistent with congressional intent. ${ }^{110}$ Representative Bruce Morrison, who sponsored the Marriage Fraud Amendments Act with Representative Slaughter, responded to the INS interpretation of the law by stating, "The INS has a legitimate concern about fraud and they may rightly require corroboration, but the law we passed made no specific requirement for medical or professional evidence." $" 111$ He went on to explain, "Professional standards are probably doing more than Congress asked for or needed. We directed the INS to write protection regulations, not fraud regulations." 112

When confronted with the potential discrepancy between congressional intent and the language of the regulations, Bonnie Derwinski, INS Director for Congressional and Public Affairs, stated that "the potential for misuse of the

McNary, Commissioner, INS 2 (Apr. 3, 1991) (on file with the author); Chun Letter, supra note 105. A simple, credible affidavit is often enough to obtain a temporary restraining order against an abuser.

Additionally, the INS accepts credible, personal statements as evidence in other immigration adjudications. For instance, foreign nationals who have a "well-founded fear of persecution" in their native lands submit personal affidavits to apply for political asylum in this country. 8 C.F.R. $\$ 208.16$; Bolanos-Hernandez v. INS, 767 F.2d 1277, 1285 (9th Cir. 1984); Matter of Villalta, Int. Dec. 3126 (BIA 1990). The situation for battered women is analogous. Battered women are fleeing oppressive situations in which they fear for their physical and mental safety, and perhaps their lives. Like refugees, they often lack the resources to substantiate their claims with professional testimony.

The INS has responded that expert evaluations are "routinely required with many applications." Letter from Bonnie Derwinski, Director of Public and Congressional Affairs, INS, to The Honorable Louise Slaughter, Member of Congress 3 (June 3, 1991) (on file with author) [hereinafter June Derwinski Letter]. Ms. Derwinski cites numerous examples, none of which are analogous to the situation of battered conditional residents. "Medical evaluations may be required for applicants for adjustment of status," but they may be obtained with the help of Medicaid through low cost health clinics. "A petition for an orphan adopted abroad requires a valid home study" by a licensed adoption agency, but these parents have enough money to adopt a child in the first place. "[C]ertifications and evaluations may be required for some applications based on occupational status or training," but those are certifications of one's own educational or occupational achievement for the purpose of immigrating under special visa permits. Id. at 3 . None of these situations is analogous to abused conditional residents who often do not have the ability to make their case without financial support.

110. The House Judiciary Committee Report states that the purpose of the battered-spouse law is "to ensure that when the U.S. citizen or permanent resident spouse or parent engages in battering or cruelty against a spouse or child, neither the spouse nor child should be entrapped in the abusive relationship by the threat of losing their legal resident status." HOUSE JUDICIARY COMM., supra note 84, at 78 (emphasis added); see also Sobieraj Interview, supra note 81 ('The word 'mental' is not in the statute. There's no reason why it should be in the regulations"). The INS may have reinserted the word "mental" as a way to legitimate the requirement for professional evaluations. See, e.g., June Derwinski Letter, supra note 109, at 2 ("[S]eparate evidentiary requirements for applications based upon extreme mental cruelty. . . . [were] found to be necessary because of the subjective nature of emotional abuse and the difficulties inherent in evaluating other than the most severe manifestations of this type of abuse."). Only the most severe forms of emotional abuse, however, warrant evaluation under the statute.

111. Interview with The Honorable Bruce Morrison, Former Member of Congress, in New Haven, Conn. (Mar. 10, 1992).

112. Id. 
waiver provision dictates the need for some type of evidence beyond the applicant's simple written assertion that he or she felt unfairly treated in a relationship."113 Representative Slaughter has responded to the INS claims pointedly: the requirement for professional evaluations for claims based on extreme mental cruelty is "obscene" given the fact that the law seeks to address a class of women who, "almost by definition," do not have access to professional help. ${ }^{114}$ Many observers have noted that immigrant women are desperate by the time they seek refuge in a shelter. ${ }^{115}$ Representative Slaughter has concluded that the INS regulations enact "excessively stringent and unprecedented proof requirements which undermine Congressional intent." 116 Linda Ikeda-Vogel, executive director of the Center for the Pacific Asian Family in Los Angeles, has concluded that, even with the batteredspouse waiver provisions, "Our clients lose out. Immigrant women are [still] at the mercy of their husbands, despite changes in the law."117

\section{Community Barriers and Fears of Bureaucratic Entanglement}

Poverty, lack of access to services, lack of privacy in extended family dwellings and closely knit communities, and fears for their own safety ${ }^{118}$ can impede many battered conditional residents from obtaining waivers under the present regulations. ${ }^{119}$ Before she calls for help, an immigrant woman must face the possibility of ending her marriage, which means accepting the social consequences attendant to divorce in her community. As in many

113. June Derwinski Letter, supra note 109 , at 2 . The statute, however, does not cover unfair treatment, but only behavior that amounts to extreme cruelty.

114. Sobieraj Interview, supra note 81. Letter from The Honorable Louise M. Slaughter, Member of Congress, to John Schroeder, Asst. Commissioner for Adjudication and Naturalization, INS 2 (Mar. 15, 1991) (on file with author) [hereinafter Slaughter-Schroeder Letter].

115. Nilda Rimonte, Domestic Violence Among Pacific Asians, in MAKING Waves: AN ANTHOLOGY OF WRITING BY AND ABOUT ASIAN AMERICAN WOMEN 327, 332-33 (Asian Women United of California ed., 1989) ("[G]iven her background and limited resources, the [immigrant] woman who chooses to leave an abusive situation, however temporarily, has taken extraordinary action. . . . For a woman raised in a conformist and other-directed culture, this choice requires immense courage."); Debbie Lee, Identifying Immigrant Battered Women, in DOMESTIC VIOLENCE, supra note 4, at III-3; Telephone Interview with Linda Ikeda-Vogel, Executive Director, Center for the Pacific Asian Family of Los Angeles, Cal. (Mar. 10, 1992) ("Women come to shelters when they are very desperate, and many still return to their abusers because they believe it is the only way to retain their legal status") [hereinafter Ikeda-Vogel Interview]; Lee Interview, supra note 9 (women attempting to obtain TRO's either have strong support behind them, or are "really, really desperate"); Orloff, supra note 15, at 6 ("[W] hen battered immigrant women do seek help, it is usually only after their problems have reached crisis proportions.").

116. Letter from The Honorable Louise M. Slaughter, Member of Congress, to The Honorable Romano Mazzoli, Chair of the House Subcomm. on International Law, Immigration and Refugees 1 (Oct. 17, 1991) (on file with author). See also Letter from The Honorable Louise M. Slaughter, Member of Congress, to Richard Sloan, Director, Policy Directives and Instructions Branch, INS 2 (June 7, 1991) (on file with author).

117. Ikeda-Vogel Interview, supra note 115.

118. Rimonte, supra note 115 , at 330 .

119. Hodgin, supra note 4 (citing Tina Shum, counselor at social service agency that has served San Francisco for 127 years, describing what she calls "cultural complications" with the law). 
nonimmigrant communities, strong mores concerning religion, marriage, divorce, family, and gender roles hinder women from stopping domestic violence and ending abusive relationships. ${ }^{120}$ In particular, traditional social systems favoring patriarchal relations ${ }^{121}$ are strong predictive variables of domestic violence. ${ }^{122}$

The normative goals of any traditional community can clash in a more obvious fashion with other facets of the legal system. Lawyers and counselors may encourage battered immigrants to seek temporary restraining orders (TRO's) to keep abusive spouses away. ${ }^{123}$ An immigrant's fear for her own safety ${ }^{124}$ may create in her a strong resistance to confrontation. ${ }^{125}$ Hence, many women, when faced with a complex bureaucracy that would force them to risk their safety by being confrontational, will capitulate and become undocumented. Others will simply return to their abusers. ${ }^{126}$

One study of undocumented immigrants found that for $64 \%$ of Latinas and $57 \%$ of Filipinas, the primary barrier to seeking help from social service agencies is the fear of deportation. ${ }^{127}$ Immigrant residents are often terrified of authority, and particularly of the INS. ${ }^{128}$ Some women do not call the police for fear that their LPR spouses, if charged with wife battery, may be

120. Frosch \& Madrigal, supra note 4, at I-3.

121. Rimonte, supra note 115 , at 328 (explaining that patriarchal familial relations and dominance of family over individual are social phenomena associated with domestic violence).

122. MildREd D. PAGelOW, WOMAN-BATTERING: VICTIMS AND THEIR EXPERIENCES 43 (1981).

123. Deeana Jang et al., Responding to Domestic Violence, in DOMESTIC VIOLENCE, supra note 4, at VIII-7 n.20 (undocumented women not precluded from obtaining TRO's or protective orders).

124. The same resistance may operate in nonimmigrant populations, as well.

125. Hodgin, supra note 4 ("This is impossible for some women, because a TRO means you have to go to court and confront the husband, face-to-face,' counselor Shum explains. 'Some would rather live with the beatings."'); Lin, supra note 9. The same may be said of many nonimmigrant communities. This is not simply a cultural distaste for confrontation, but is based on a woman's concern for her safety. The resistance to confrontation may also break down along class lines.

126. Lee Interview, supra note 9.

127. HOGELAND \& ROSEN, supra note 4, at 17 . Simply because an immigrant fears deportation does not mean that she has been duplicitous in her acquisition of conditional status or that she entered her marriage fraudulently. A fear of deportation does not imply anything about her rationale for coming to this country-only that she would rather not return to her native land for any number of reasons. In their native lands, women may face unemployment, extreme poverty, or political repression. If family and community ties are established in this country, deportation means separation from close ones, with perhaps no means of support. These problems may be particularly acute for battered immigrant women. Women may be deported without their children, forcing mothers to leave the children with their abusive spouses. Battered women may also face social ostracism if forced to return to their native lands. Traditional families and communities may reject divorced women or women who have left their husbands. Hodgin, supra note 4. As outcasts, they may be literally unable to rejoin their former societies. Id. Alice Fernandez, Director of the Victim Services Agency in the Bronx, asserts that certain immigrant women are thus "held hostage" by their husbands: "The message is: if you tell anybody what I'm doing to you, they are going to ship your ass back home. And for these women, there is nothing more terrible than that . . . . Sometimes their response is: I would rather be dead in this country than go back home." Walt, supra note 1.

128. Hodgin, supra note 4. A few communities have affirmative "city of refuge" policies whereby local police have no obligation to notify INS about undocumented aliens. Lee Interview, supra note 9. But "there are still risks in contacting the police because police will usually call the INS if the perpetrator is undocumented." Id. Cf. Gonzales v. City of Peoria, 722 F.2d 468, 474-77 (9th Cir. 1983) (holding that police have authority to arrest for violations of Immigration and Nationality Act "where there is probable cause to believe that the arrestee has illegally entered the United States."). 
deported. ${ }^{129}$ Economic dependence and fear of being forced to leave the country with their children if their spouses were deported ${ }^{130}$ keeps other women wary of police. Many would rather stay in abusive relationships than risk facing the INS and deportation. ${ }^{131}$

\section{SOLUTIONS}

Solutions to the problems of battered immigrant women advanced by other commentators have not been wholly adequate. Some have suggested that waivers of spousal petition requirements automatically be granted to battered conditional residents who have borne children of their marriages. ${ }^{132}$ They argue that the existence of children born from the relationship should be treated as proof that the marriage was not fraudulently entered into for the purpose of obtaining legal immigration status. This suggestion increases immigrants' ability to establish marital legitimacy, but not to establish battery. ${ }^{133}$ This suggestion, therefore, does not address the problem of spouse abuse directly.

As outlined above, current law allows husbands to control the petitioning process for those lacking conditional residency status, establishes unreasonable evidence requirements, and ignores both the community barriers to accessing help and immigrants' fears of bureaucratic entanglement. A full response to the plight of battered conditional residents must address each of these inadequacies; it should allow women to self-petition for their immigration status, establish reasonable evidence requirements, and break down community

129. LPR's can be deported if convicted of two crimes of moral turpitude. It is not clear whether spousal abuse constitutes a crime involving moral turpitude. See, e.g., Garcia-Lopez v. INS, 923 F.2d 72, $75 \mathrm{n.2}$ (7th Cir. 1991) (weighing foreign national's threats to his wife as factors disfavoring voluntary departure); Crouch v. INS, No. A11-969-628, 1991 U.S. App. LEXIS 10768 (9th Cir. May 13, 1991) (finding no abuse of BIA discretion in denial of waiver of deportation to foreign national convicted of rape and charged with assault against his wife); Matter of Lemhammad, No. A-27935756, Interim Decision 3151,1991 B.I.A. LEXIS 13 (holding that criminal conviction for domestic assault provides justification for denial of voluntary departure); In the Matter of P-, 3 I. \& N. Dec. 31, at 6-7 (B.I.A. 1947) (finding that simple assault is generally not held to involve moral turpitude; assault with intent to do bodily harm constitutes a crime involving moral turpitude); In the Matter of $\mathrm{G}-\mathrm{R}-, 2$ I. \& N. Dec. 733 (B.I.A. 1946) (finding assault with a deadly weapon a crime involving moral turpitude).

130. Courts have found that a citizen child's constitutional rights are not violated when a child's parent is deported, even if the child must be deported as well. Acosta v. Gaffney, 558 F.2d 1153, 1157 (3rd Cir. 1977); Perdido v. INS, 420 F.2d 1179, 1181 (5th Cir. 1969).

131. Ikeda-Vogel Interview, supra note 115; see also Lee, Identifying Immigrant Battered Women, in DOMESTIC VIOLENCE, supra note 4, at II-7.

132. Janet M. Calvo, Spouse-Based Immigration Laws: The Legacies of Coverture, 28 SAN DIEGo L. REV. 593, 628 (1991). The INS presently accepts birth certificates of children born of the marriage as evidence of good faith. 8 C.F.R. $\$ 216.5$ (e)(2)(iii). Professor Calvo argues that "proof of the existence of a child born of the marriage should not just be a factor, but should preclude any finding that the alien spouse did not enter the marriage in good faith." Id. at 630-31. Representative Louise Slaughter has advocated a similar position. See 136 CoNG. REC. H8642 (daily ed. Oct. 2, 1990) (statement of Rep. Slaughter).

133. Unless, of course, Professor Calvo would have the INS issue waivers of conditional residency to any woman who became pregnant or bore children from a marriage. 
barriers by encouraging confident interaction with the bureaucracy. These changes will not solve the problem of wife abuse. They will, however, mitigate the ways in which immigration status is now used against battered immigrants.

\section{A. Allow Self-Petitioning for Immigration Status}

Current law affords husbands a great degree of control over the immigration status of their immigrant spouses. If her husband refuses-however arbitrarily - to cooperate in the petitioning process from the onset of the relationship, an immigrant wife is out of luck, despite the existence of the battered-spouse waiver for those who already have conditional status. Battered immigrant wives of husbands who refuse to petition for their immigration status in the first place have "fallen through the cracks," and thus lack a remedy for their plight. Congress should amend the statute to allow all immigrant women to self-petition for their immigration status and to selfpetition to adjust from conditional to permanent status. ${ }^{134}$

This change would limit batterers' ability to hold the threat of deportation over the heads of immigrant women. Women would be allowed to petition the INS independently, regardless of their husbands' wishes. Women who selfpetition would still face the threat of deportation, since the INS could find their marriages to be fraudulent. However, for those who have proof that their marriages were valid (such as marriage certificates, wedding photos, or letters between the spouses), the ability to self-petition will nearly eliminate that threat. Many abused immigrant women will still desire as little interaction with the INS as possible, and will, therefore, remain unlikely to petition for a battered-spouse waiver even if they are battered. By starting the two-year fraud clock earlier (when a woman files for her own conditional residence), however, those women who choose not to petition for battered-spouse waivers, for whatever reason, would have to stay with their husbands for a shorter time period before they could leave their marriages. If the system allowed women to initiate and terminate their own conditional residence status on their own initiative, then husbands would not be able to control their wives' immigration status by refusing to petition.

134. Professor Calvo has advocated this position. See Calvo, supra note 132 , at 625 . In late July 1992 , Representatives Mazzoli and Slaughter introduced a bill that was referred to the House Judiciary Committee and the House Subcommittee on International Law, Immigration, and Refugees. The bill would permit those who already had conditional residency to petition for their own immigration classification. H.R. 5693. That bill is unfortunately now "dead in the water" according to Representative Slaughter's office due to the end of the Congressional session. They plan to re-introduce the bill next session. Telephone Interview with Sandra Sobieraj, legislative aide to the Honorable Louise Slaughter (December 9, 1992). 


\section{B. Establish a Reasonable Evidence Requirement}

Battered conditional residents are often unemployed and have little social mobility. Those who come here poor may have little or no independent financial resources. To obtain waivers based on extreme cruelty, a reasonable evidentiary requirement would not require these women to present testimony from psychiatrists, psychologists, and licensed clinical social workers. Such a burden would be reasonable only if the INS provided these professional services free of charge to poor immigrants. As in the case of representation of indigent people, the process is neither equitable nor just if a person does not have the ability to present her case. ${ }^{135}$

Yet, poverty is not the only factor preventing immigrant women from seeking out professional expertise; community also plays a role. Abused conditional residents may not seek help from social service agencies in light of their own cultural definitions of family and community. Battered conditional residents may confide in members of an extended family, religious leaders, and others long before they consider seeking help outside the immigrant community.

To establish a reasonable evidentiary requirement, the INS should change its regulations to allow women to submit a broad range of evidence. ${ }^{136}$ In addition to the testimony of police, psychiatrists, psychologists, clinical social workers, and doctors, the INS should hear statements of family members, friends, religious workers, battered women's shelter staff, school teachers and administrators, immigrant community advocates who have witnessed the abuse or its effects, and others who can present pertinent evidence. ${ }^{137}$ The decisionmakers' role is to evaluate the credibility of witnesses and evidence. They should not restrict the information they consider to a few sources, such

135. This Note does not assume that the United States owes foreign nationals the benefits of immigration. A foreign national who seeks entry to this country has no right to enter. United States ex rel. Knauff v. Shaughnessy, 338 U.S. 537, 542, 544 (1950) ("[A]n alien who seeks admission to this country may not do so under any claim of right. ... Whatever the procedure authorized by Congress is, it is due process as far as an alien denied entry is concerned.") A foreign national who has already gained entry into this country, however, does have constitutional due process rights. Landon v. Plasencia, 459 U.S. 21,32 (1982) ("[O]nce an alien gains admission to our country and begins to develop the ties that go with permanent residence, his constitutional status changes accordingly."); Kwong Hai Chew v. Colding, 344 U.S. 590, 601 (1953) (resident aliens have the "constitutional right to procedural due process"). A conditional resident possesses all the rights of a lawful permanent resident. 8 C.F.R. $\$ 216.1$ (a conditional resident has "the rights, privileges, responsibilities and duties which apply to all other lawful permanent residents."). To the extent that conditional residents possess due process rights, the procedures by which the INS denies them waivers of the two-year conditional status must comport with basic notions of equity and justice.

136. Representatives Mazzoli and Slaughter's bill would have permitted conditional residents to submit any credible evidence on their behalf whether or not it was supported by licensed professionals. See supra note 134.

137. An author of the battered spouse waiver has stated, "Acceptable proof of battering or extreme cruelty should include affidavits from the abused or others who observed the abuse, reports from shelters, religious workers, community agencies, and state or local employees." Slaughter-Schroeder Letter, supra note 114 , at 1 . 
as expensive professional testimony, that remain financially, culturally, and linguistically inaccessible to most immigrant women.

Since the statute does not mandate the use of professional evidence, this change would simply require an alteration in the INS regulations. A suit challenging the INS interpretation of the statute would likely be unsuccessful, given judicial deference to agency interpretations of statutes. ${ }^{138}$

\section{Encourage Confident Interaction with Bureaucracy}

To diffuse the fears of bureaucratic entanglement which many immigrants understandably hold, Congress should amend the statute to require the INS to distribute information about immigrant women's legal rights and options. ${ }^{139}$ Immigrant women could then make informed choices about their safety and the relative risks of behaviors. The INS could enlist social service agencies having contact with abused immigrants-hospices, hospitals, police stations, clinics, immigrant community centers, battered women's shelters, cultural centers, rape crisis hotlines, religious institutions, schools, and others-to distribute pamphlets and utilize other media to explain that women can leave battering relationships without automatically being deported.

There is an even more efficient solution. The law presently requires that the INS inform conditional residents of the joint petition requirements to terminate their conditional status and achieve permanent status. ${ }^{140}$ Information about the battered-spouse waiver to the joint petitioning requirement could easily be disseminated at the same time. Coupled with the ability to self-petition, an immigrant could be informed from the beginning of the process (when she initially petitions for residency status) of her rights and responsibilities as a conditional resident, thereby nearly eliminating the risk

138. See Chevron, U.S.A., Inc. v. Natural Resources Defense Council, 467 U.S. 837 (1984). Chevron held that if a statute's plain language is contrary to agency regulations, then the regulations should be struck down. However, if the statute does not address the question directly, the courts should ask whether the regulation is a reasonable interpretation of the statute. If so, courts should defer. Id. at 842-43.

139. Translation of the legal rules would further ensure that immigrants understood the law. This change in INS policy would not contradict the compelling reasons for encouraging immigrants' mastery of the English language and assimilation into the United States polity. See Peter H. Schuck, The Emerging Political Consensus on Immigration Law, 5 GEO. IMMIG. L.J. 1 (1991). Though the use of English should be encouraged to make it easier for immigrants to function and succeed in an English-dominated society, there will usually be, even under ideal circumstances, a time lag before an immigrant will understand the language fluently. Especially since the petitioning process will occur during the first few years of an immigrant's stay in this country, an immigrant's knowledge of English will be most limited at that time. Further, there is little evidence to suggest that the translation of legal information would significantly affect the already powerful incentives to learn English. See id. at 32; see also Robert Suro, Hispanic Pragmatism Seen in Survey, N.Y. TiMES, Dec. 15, 1992, at A20 ("economic self-interest and a driving commitment to be part of American society" create strong incentives to learn English).

140. Notification Requirements, 8 C.F.R. $\$ 216.2$ (1992). This strategy is analogous to the outreach requirements of IRCA which provided immigrants information on their legal options. See Selected Statements of Witnesses Before the House Judiciary Subcommittee on Immigration, Refugees, and International Law on 1986 Immigration Law, Statement of Alan Nelson, Commissioner of the INS, BUREAU NATIONAL AFFAIRS DAILY LABOR RePORT, May 18, 1989, at D1. 
that she would remain ignorant of the waiver and therefore be unable to leave a batterer.

Some immigrant advocacy groups do distribute pamphlets that explain the legal options available to battered immigrants, but only to those women they can reach with their limited funds. In order for this information to reach an adequate number of immigrant women, Congress should direct the INS to create and provide such materials on a more extensive basis.

\section{RESULt OF THESE CHANGES}

Implementing these changes to immigration laws would facilitate access to battered-spouse waivers. To some, this may signal a potential increase in fraudulent claims. In meetings with congressional leaders, INS officials expressed their suspicion that even the present waiver provision would be frequently "abused"- that women would attempt to falsify domestic battery as a means of staying in the country. ${ }^{141}$ INS officials are reported to have claimed that if they permitted the testimony of battered women's shelter workers as evidence to corroborate claims of extreme cruelty, shelters would "try to make money off immigrant women by selling them false affidavits." 142

In actuality, however, the risk that these rather modest changes in the law would open the proverbial immigration floodgates is minimal. First, to be attractive as an avenue for fraud, an immigrant would have to be willing to fabricate domestic abuse. The notion that immigrants would be willing to beat themselves to create the physical signs of domestic abuse seems farfetched, if not implausible. The concern that battered women's shelters or doctors would sell false affidavits to immigrants wishing to fabricate claims of domestic assault seems equally improbable.

Second, alternatives to waiving conditional status through proving battery would be more attractive to those who wish to attain legal status fraudulently (e.g., obtaining a good faith termination waiver). ${ }^{143}$ If the INS does not find an immigrant's story of abuse credible when she comes forward to obtain a battered-spouse waiver, the INS will begin deportation proceedings against her. An alternative route of fraud such as continuing a bogus marriage for two years would require less interaction with the INS and less risk of deportation than would applying for a battered-spouse waiver. If these facts are true, the

141. Sobieraj Interview, supra note 81 ("The INS was resistant to the whole concept of the legislation.").

142. Id.

143. The IMFA has been of dubious fraud prevention value. See Tucker, supra note 60 , at 48 (discussing ease of maintaining "appearance of valid relationship for two years without great inconvenience, despite the Marriage Fraud Act"); see also David Moyce, Petitioning on Behalf of an Alien Spouse: Due Process Under the Immigration Laws, 74 CAL. L. REV. 1747 (1986) (criticizing scrutiny leveled at immigrant/citizen marriages as violative of due process, particularly what he calls "marital privacy"). 
changes proposed in how the battered-spouse waiver operates would not significantly affect the incentives to commit marriage fraud in the first place.

Third, even if there were those, at the margins, who might find the possibility of fabricating abuse more attractive than other modes of fraudulently obtaining legal status, when one compares the potential number of women who might be successful at this bizarre method of fraud to the large number of battered women these changes would potentially rescue from abuse, the weight of evidence is decidedly on the side of changing the law.

Fourth, the availability of broader options for documenting abuse would not negate a conditional resident's legal obligation to prove that her marriage was valid from its inception. Each person seeking a battered-spouse waiver would still be required to validate her marriage in the eyes of the INS. Women who present sufficient evidence to substantiate their marriages (marriage certificates, wedding photographs, joint bank accounts, letters, etc.) have not behaved fraudulently. They have entered into their marriages in good faith; they have not "entered by stealth" or "found community in America only after flouting th[e] law." 144

Fifth, the changes suggested herein do not discard conditional residency or other requirements; they simply attempt to make the law what it already purports to be-an exception to conditional residency requirements for those who are abused by their LPR or citizen spouses. If immigration law provides a legal exception to conditional residency requirements for those who are abused, immigrant women should be made aware of that provision and the law should be effective and appropriate for the community it attempts to serve. Autonomy for immigrants petitioning the INS, equitable evidentiary requirements, and truthful information distribution in immigrant communities are necessary modifications. The proposed changes ask only that immigrants who marry citizens or LPR's legitimately be allowed to leave those relationships if they become abusive, without risking deportation. ${ }^{145}$

Finally, these proposals would create important positive incentives in immigrant communities. For instance, the ability to self-petition would increase wives' legal independence from their husbands. Autonomous interaction with the INS would afford immigrant women more independence generally. Accurate, multilingual information from the INS, dispersed through community centers, could be a means for decreasing immigrant women's isolation and fear of the immigration process in general. Thus, the incentives these legal changes would create would actually help alleviate some of the factors-dependency, isolation, and ignorance-that contribute to immigrant women's high risk for abuse in the first place.

144. Peter H. Schuck, The Transformation of Immigration Law, 84 CoLUM. L. REV. 1, 87 (1984).

145. The fear of deportation does not, in itself, indicate fraudulent acquisition of legal status. See supra note 127 . 


\section{CONCLUSION}

Imagine the experiences of a Haitian woman named Celeste. She marries an American citizen, immigrates to this country and believes her husband when he tells her that he has applied for her conditional residency. He has not. He begins abusing her within months of the marriage and convinces her that she will be deported if she tells anyone. He refuses to let her eat for days at a time, use the phone, or leave the house. Because she does not speak English, she does not know what resources might be available if she flees the abusive situation. Moreover, she is afraid to leave her spouse because of the threat of deportation back to Haiti.

What can Celeste do under the status quo? Technically she could attempt to obtain a legal waiver of conditional residency, but she is not aware of this law. There is little possibility that she will come to know about it because she does not speak English and does not live in a community with many immigrants. Even if she knew about the waiver provision, because she does not presently have conditional resident status, she cannot qualify for a waiver at all. Even if she were a conditional resident, the INS might require her to get professional testimony to determine whether or not she suffered extreme mental cruelty. Without independent financial resources, she cannot meet this standard. Celeste must stay and endure the abuse.

What would Celeste do if these changes were implemented? First, she would petition the INS for her own immigration status from the moment she immigrates to this country. Her husband would not control that process. Second, she would be informed about the battered-spouse waiver to the twoyear conditional status requirement because the INS would provide her with that information when she initially applies for her status. Third, she would not need to obtain expensive professional affidavits about her mental state to obtain a battered-spouse waiver. Therefore her autonomy and ability to leave her abusive husband would be greatly increased.

The abuse suffered by conditional residents is easily ignored. Immigrant women constitute one of the groups most vulnerable to exploitation in our society, yet their needs remain unaddressed by the legal system. Tougher marriage fraud laws and their inadequate amendments have exacerbated the societal problems of wife abuse and bound battered conditional residents to their abusers. ${ }^{146}$ An INS spokesperson admits that the two-year conditional requirement has become "equated to indentured servitude." 147 The terror and dependency under which abused conditional residents live prompted one sociologist to observe that "many Asian and Mexican women are kept virtual

146. Hodgin, supra note 4.

147. Lin, supra note 9; see Walt, supra note 1 (citing INS spokesperson who says, "You can't place spouses in servitude for two years just because they're conditional residents."). 
prisoners and slaves, living isolated lives of great fear and constant threat by their spouses of 'sending them back' - without their children."148

The idea of severely battered conditional residents living in conditions of "enslavement" may be more than metaphor or hyperbole. Claims under the Thirteenth Amendment, ${ }^{149}$ which abolished slavery and all its accoutrements, have successfully challenged peonage, ${ }^{150}$ forced prostitution, ${ }^{151}$ and forced migrant labor. ${ }^{152}$ Recently, legal scholars have urged a reanimation of the Thirteenth Amendment in a decidedly modern context. ${ }^{153}$ They have argued that severely abused children ${ }^{154}$ and severely battered women ${ }^{155}$ each have

148. PAGELOW, supra note 122 , at 97 ; see also Leung, supra note 40 (citing family counselor at church-affiliated social service organization in San Francisco's Chinatown as saying that some husbands reportedly treat their wives "more like slave servants than equal partners"); Villapando, supra note 32, at 325 (noting that, after investigating "mail-order bride" industry, sociologist observed that many men utilizing the service "beat their wives and treat them little better than slaves."); see supra note 130 for information on citizen children's constitutional rights.

149. Section One of the Thirteenth Amendment to the United States Constitution declares that "[n]either slavery nor involuntary servitude, except as a punishment for crime whereof the party shall have been duly convicted, shall exist within the United States, or any place subject to their jurisdiction." U.S. CoNST. amend. XIII, $\S 1$. Section Two provides a congressional grant of authority to implement $\S 1$ : "Congress shall have power to enforce this article by appropriate legislation." U.S. CONST. amend. XIII, $\S 2$. The Supreme Court has declared that "Congress has the power under the Thirteenth Amendment rationally to determine what are the badges and the incidents of slavery, and the authority to translate that determination into effective legislation." Jones v. Alfred H. Mayer Co., 392 U.S. 409, 440 (1968). Since the post-Civil War era, however, Congress has enacted little legislation that has expressly relied upon the Thirteenth Amendment. LAURENCE H. TRIBE, AMERICAN CONSTITUTIONAL LAW 333 (2d ed. 1988).

150. Peonage, servitude of forced labor to pay off a debt, violates the Thirteenth Amendment. See, e.g., Pollock v. Williams, 322 U.S. 4 (1944); Taylor v. Georgia, 315 U.S. 25 (1942); United States v. Reynolds, 235 U.S. 133 (1914); Bailey v. Alabama, 219 U.S. 219 (1911); Clyatt v. United States, 197 U.S. 207 (1905).

151. In Pierce v. United States, the Fifth Circuit concluded that Joel Pierce held young women in involuntary servitude by forcing them into prostitution. 146 F. 2d 84 (5th Cir. 1944), cert denied, 324 U.S. 873 (1945).

152. See, e.g., United States v. Warren, 772 F.2d 827 (11th Cir. 1985); United States v. Mussry, 726 F.2d 1448, 1453-56 (9th Cir. 1984), cert. denied, 469 U.S. 855 (1984); United States v. Harris, 701 F.2d 1095 (4th Cir. 1983); United States v. Booker, 655 F.2d 562 (4th Cir. 1981); United States v. Bibbs, 564 F.2d 1165, 1168 (5th Cir. 1977). Cf. U.S. v. Shackney, 333 F.2d 475 (2d Cir. 1964).

153. For a discussion of the modern context, see generally John M. Cook, Note, Involuntary Servitude: Modern Conditions Addressed in United States v. Mussry, 34 CATH. U. L. REV. 153 (1984). For analysis of the role of labor in the Thirteenth Amendment, see Lea S. VanderVelde, The Labor Vision of the Thirteenth Amendment, 138 U. PA. L. REV. 437 (1989).

The Supreme Court's first articulation of the scope of the Thirteenth Amendment is consistent with a modern interpretation of its scope. See Slaughter-House Cases, 83 U.S. (16 Wall.) 36, 72 (1873) (noting that "while negro slavery alone was in the mind of the Congress which proposed the thirteenth article, it forbids any other kind of slavery, now or hereafter").

154. Akhil R. Amar \& Daniel Widawsky, Child Abuse As Slavery: A Thirteenth Amendment Response to Deshaney, 105 HARV. L. REV. 1359 (1992). Amar and Widawsky define slavery, for the purposes of the Thirteenth Amendment, as a "power relation of domination, degradation and subservience, in which human beings are treated as chattel, not persons." Id. at 1365. Amar and Widawsky persuasively argue that when a parent systematically perverts the responsibility of custody by assaulting his/her child, "the parent violates the Thirteenth Amendment and should be subject to suit." Id. at 1364. Importantly, Amar and Widawsky also argue that the Thirteenth Amendment "imposes a duty on the state to provide an adequate apparatus to enforce the emancipation of all persons within its jurisdiction." Id. at 1380. See also Civil Rights Cases, 109 U.S. 3, 20 (1883) ("[T] he amendment is not a mere prohibition of State laws establishing or upholding slavery, but an absolute declaration that slavery or involuntary servitude shall not exist in any part of the United States."). 
legitimate Thirteenth Amendment claims against their abusers. Constructing the precise argument of a potential Thirteenth Amendment challenge for conditional residents is beyond the scope of this Note. It suffices to say that laws which make an immigrant's legal status dependent upon the actions of an abusive spouse, placing her at risk for a kind of involuntary servitude, may pose problems of constitutional magnitude.

Conditional residency laws afford batterers a license to abuse their immigrant spouses. This abuse harms not just the women who will sustain the bruises, but also this nation's claim that it stands as a beacon of liberty in the world. It is a cruel irony that many immigrant women left conditions of political turmoil and extreme poverty in their homelands to find a better life in this country. Newly wedded, immigrant women hoped to discover a land of freedom and opportunity. Many have found, instead, an existence impoverished by confinement, brutality, and the terror of nowhere to turn.

155. Joyce E. McConnell, Beyond Metaphor: Battered Women, Involuntary Servitude and the Thirteenth Amendment, 4 YALE J.L. \& FEMINISM 207 (1992). McConnell persuasively argues that to "focus only on the economic aspect of slavery as a system of production in the public sphere is to remove slavery from its hellish private context." Id. at 217. McConnell argues that extreme domestic battery, including "coerced sexual services," "should be considered as falling within the scope of the involuntary servitude prohibition." Id. at 218. For another innovative application of the Thirteenth Amendment in a modern context, see Andrew Koppelman, Forced Labor: A Thirteenth Amendment Defense of Abortion, 84 Nw. U. L. REV. 480 (1990). 